\title{
THERMAL POWER CALIBRATION OF THE ENRICO FERMI REACTOR
}

\author{
R. C. Callen \\ H. J. Allgeier*
}

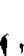




\section{DISCLAIMER}

This report was prepared as an account of work sponsored by an agency of the United States Government. Neither the United States Government nor any agency Thereof, nor any of their employees, makes any warranty, express or implied, or assumes any legal liability or responsibility for the accuracy, completeness, or usefulness of any information, apparatus, product, or process disclosed, or represents that its use would not infringe privately owned rights. Reference herein to any specific commercial product, process, or service by trade name, trademark, manufacturer, or otherwise does not necessarily constitute or imply its endorsement, recommendation, or favoring by the United States Government or any agency thereof. The views and opinions of authors expressed herein do not necessarily state or reflect those of the United States Government or any agency thereof. 


\section{DISCLAIMER}

Portions of this document may be illegible in electronic image products. Images are produced from the best available original document. 
•

$\pi$

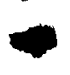




\section{ABSTRACT}

This report describes experiments of thermal power calibration of the Enrico Fermi reactor. Preliminary experiments were required to examine temperature detector response and determine system dissipative heat losses. Three determinations were made of reactor power at levels between 85 and $100 \mathrm{Mw}$. The technique employed was to determine the power removed by the feedwater-steam system in the form of superheated steam; this was corrected for extraneous power sources to obtain reactor power.

Errors resulting from experimental and operational sources are discussed and comparison of results with those of a nuclear calibration is presented. 
FOREWORD

This report is one of a series of reports on the low-power (up to 1 Mwt) and high-power (up to $200 \mathrm{Mwt}$ ) nuclear testing of the Enrico Fermi reactor. The Nuclear Test Program is planned, directed and evaluated by Atomic Power Development Associates, Inc. (APDA). The tests are conducted by Power Reactor Development Company (PRDC). The reactor proper is owned and operated by PRDC. The steam generators and electrical generating facilities are owned by The Detroit Edison Company (DECo).

Many individuals have contributed to the nuclear testing of the Enrico Fermi reactor. Listed below are those, exclusive of the authors, who have made significant contributions to the work described in this report.

\section{PLANNING AND ANALYSIS}

R. L. DeMumbrum

DECo

P. M. Harrigan

PRDC

H. A. Wilber

PRDC

TESTING

F. J. Locke

DECo 


\section{SUMMAR Y}

A series of experiments was performed in the Enrico Fermi Atomic Power Plant to determine reactor power. A heat balance method was used and three calibration tests were performed at power levels between 85 and $100 \mathrm{Mw}$. The tests were performed after power, flows, and system temperatures had been stabilized. The power transferred at the steam generators (water-side terminals) was then measured. To obtain reactor power, corrections were required for the contribution of extraneous power sources, e.g., primary coolant system pumps. A series of isothermal measurements was performed over the temperature range of the heat balance tests to evaluate system dissipative heat losses to the surroundings. A series of tests was also required to examine the various temperature detector responses and to provide appropriate reading corrections.

The operating conditions for these tests could not be optimized since other investigations were being performed at the same time. The reported error analyses evaluated these effects. Although reactor power was determined within an estimated probable error of about +4 per cent, the optimum error attainable may be as small as \pm 2 per cent.

A comparison of the thermal calibration with the nuclear power calibration was made. The indicated power levels for the three tests obtained from the two methods agreed to within 2 per cent.

ERRATA

PLEASE INSERT THIS PAGE INTO YOUR COPY OF

REPORT APDA-NTS- 16. 
TABLE OF CONTENTS

$\underline{\text { Page }}$

LIST OF ILLUSTRATIONS $\ldots \ldots \ldots \ldots \ldots \ldots \ldots \ldots \ldots \ldots \ldots \ldots$

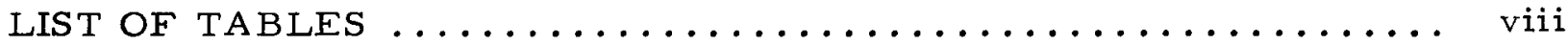

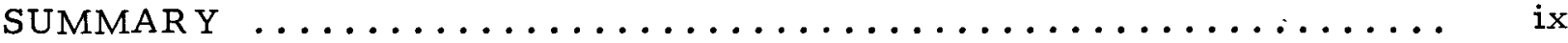

I. PLANT AND OPER ATIONAL DESCRIPTION $\ldots \ldots \ldots \ldots \ldots \ldots \ldots$

A. CORE AND BLANKET .................... 1

B. REACTOR VESSEL INTERNAL STRUCTURES ......... 4

C. PRIMARY SODIUM COOLANT SYSTEM ............ 4

D. SECONDARY SODIUM AND FEEDWATER-STEAM

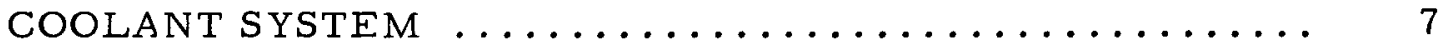

E. MODE OF OPERATION $\ldots \ldots \ldots \ldots \ldots \ldots \ldots \ldots \ldots \ldots \ldots \ldots$

II. DESCRIPTION OF TESTS $\ldots \ldots \ldots \ldots \ldots \ldots \ldots \ldots \ldots$

III. TEST INSTRUMENTATION AND EXPERIMENTAL PROCEDURES ........................ 13

A. TEST INSTRUMENTATION $\ldots \ldots \ldots \ldots \ldots \ldots \ldots \ldots \ldots \ldots \ldots$

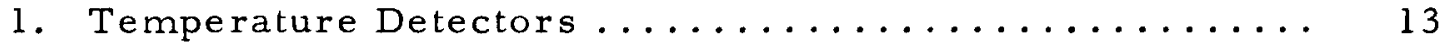

2. Manometers and Flow Nozzles ................ 14

3. Monitors of Neutron Level, Flow, and

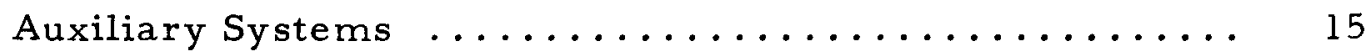

B. EXPERIMENTAL PROCEDURES $\ldots \ldots \ldots \ldots \ldots \ldots \ldots \ldots \ldots \ldots$

1. Temperature Detector Comparisons ............ 16

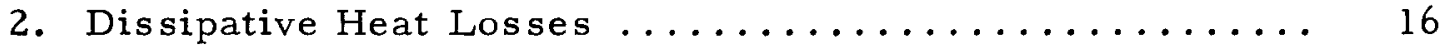

3. Heat Balance Experiment .................. 20

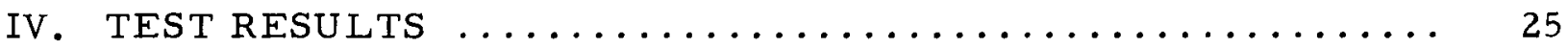

A. TEMPERATURE DETECTOR ISOTHERMAL

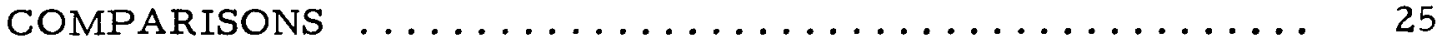

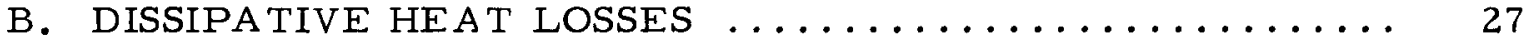

C. HEAT BALANCE TEST .................... 29

CONCLUSIONS $\ldots \ldots \ldots \ldots \ldots \ldots \ldots \ldots \ldots \ldots \ldots \ldots \ldots \ldots \ldots \ldots \ldots \ldots$

APPENDIX A: Comparison of Heat Balance and Nuclear

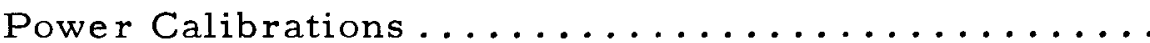

APPENDIX B: Sodium Flowmeter Calibrations .............. 43

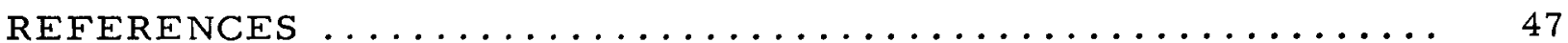




\section{LIST OF ILLUSTRATIONS}

Fig.

$\underline{\text { Page }}$

1. Perspective View of Reactor $\ldots \ldots \ldots \ldots \ldots \ldots \ldots \ldots \ldots, 2$

2. Heat Removal Systems $\ldots \ldots \ldots \ldots \ldots \ldots \ldots \ldots \ldots \ldots \ldots$

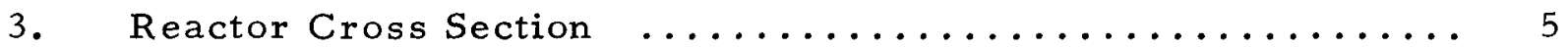

4. Elevation of Reactor Containment Vessel $\ldots \ldots \ldots \ldots \ldots \ldots 6$

5. Location of Instruments Used in Tests $\ldots \ldots \ldots \ldots \ldots \ldots . \ldots 17$

6. Dissipative Heat Losses $\ldots \ldots \ldots \ldots \ldots \ldots \ldots \ldots \ldots \ldots . \ldots \ldots$

A-1 Comparison of the Nuclear Power Calibration

With the Three Thermal Power Calibrations ............. 41

\section{LIST OF TABLES}

$\underline{\text { Table }} \quad \underline{\text { Page }}$

1. Plant Temperature Detectors .................... 14

2. Operational Summary - Heat Balance Tests ............ 21

3. Test Results - Temperature Detector Comparison ......... 26

4. Test Results - Dissipative Heat Loss $\ldots \ldots \ldots \ldots \ldots \ldots \ldots 28$

5. Test Data - Heat Balance ..................... 30

6. Test Results - Heat Balance $\ldots \ldots \ldots \ldots \ldots \ldots \ldots \ldots \ldots \ldots \ldots \ldots \ldots$

7. Error Analysis - Heat Balance .................. 32

8. Temperature Drift Data - Heat Balance .............. 34

A. 1 Comparison of Thermal and Nuclear Determinations of Reactor Power .......................... 40

B. 1 Fermi Sodium Flowmeter Calibration $\ldots \ldots \ldots \ldots \ldots \ldots . \ldots 4$ 


\section{PLANT AND OPERATIONAL DESCRIPTION}

The fast neutron breeder reactor of the Enrico Fermi Atomic Power Plant, shown in perspective in Fig. 1, is cooled by sodium and operated at essentially atmospheric pressure. The reactor is housed in a stainless steel reactor vessel, sealed at the top by the rotating shield plug and supplied with coolant by three parallel primary sodium coolant loops. The unmoderated core of zirconium-clad pins of enriched uranium-molybdenum alloy is surrounded by breeder blankets of depleted uranium. Heat is transferred from the radioactive primary sodium loops in three intermediate heat exchangers (Fig. 2) to nonradioactive secondary sodium loops and, thence, to three once-through steam generators. Here, superheated steam is produced to operate the conventional turbine generator. Electrical power is supplied to the Detroit Edison Company grid on a base-load basis. The plant was constructed to operate at $430 \mathrm{Mwt}$ and produce $156 \mathrm{Mw}$ of electrical power; however, the maximum power of the reactor with the first core (Core A) is $200 \mathrm{Mwt}$.

\section{A. CORE AND BLANKET}

The core and blanket are located in the lower reactor vessel and consist of 2.646-in.-square subassemblies arranged to approximate a cylinder $80 \mathrm{in.}$ in diam and $70 \mathrm{in.} \mathrm{high.} \mathrm{The} \mathrm{first} \mathrm{core} \mathrm{in} \mathrm{use} \mathrm{(Core} \mathrm{A)} \mathrm{approximates}$ a cylinder 31 in. in diam and 31 in. high. Fuel, in the form of a pin 0.148 in. in diam, is uranium-10 w/o molybdenum alloy with the uranium enriched to 25.6 per cent U-235. Each core subassembly has a total mass of 4.75 $\mathrm{kg}$ of U-235 and contains 140 fuel pins, each clad with 5-mil-thick zirconium. Each end is blanketed by a section of pins of depleted uranium-3 w/o molybdenum alloy sodium bonded in stainless steel tubes of 0.443 -in. OD. The tubes are also used in the inner radial blanket (IR B) subassemblies and outer radial blanket (ORB) subas semblies.

Two support plates joined by vertical ribs and located in the lower reactor vessel provide the basic definition of the reactor in a rectangula $r$ array. Holes spaced on 2.693-in. centers accept the subassemblies. The central structure supports the core and IRB subassemblies and directs sodium into them from a high-pressure plenum. The support plates are supported, in turn, by the outer structure which accepts the OR B subassemblies. A holddown mechanism (HDM) mounted above the high-pressure plenum subassemblies prevents them from being lifted by the hydraulic forces developed. The HDM also serves to gather the subassemblies radially to form a tight core. 
• 


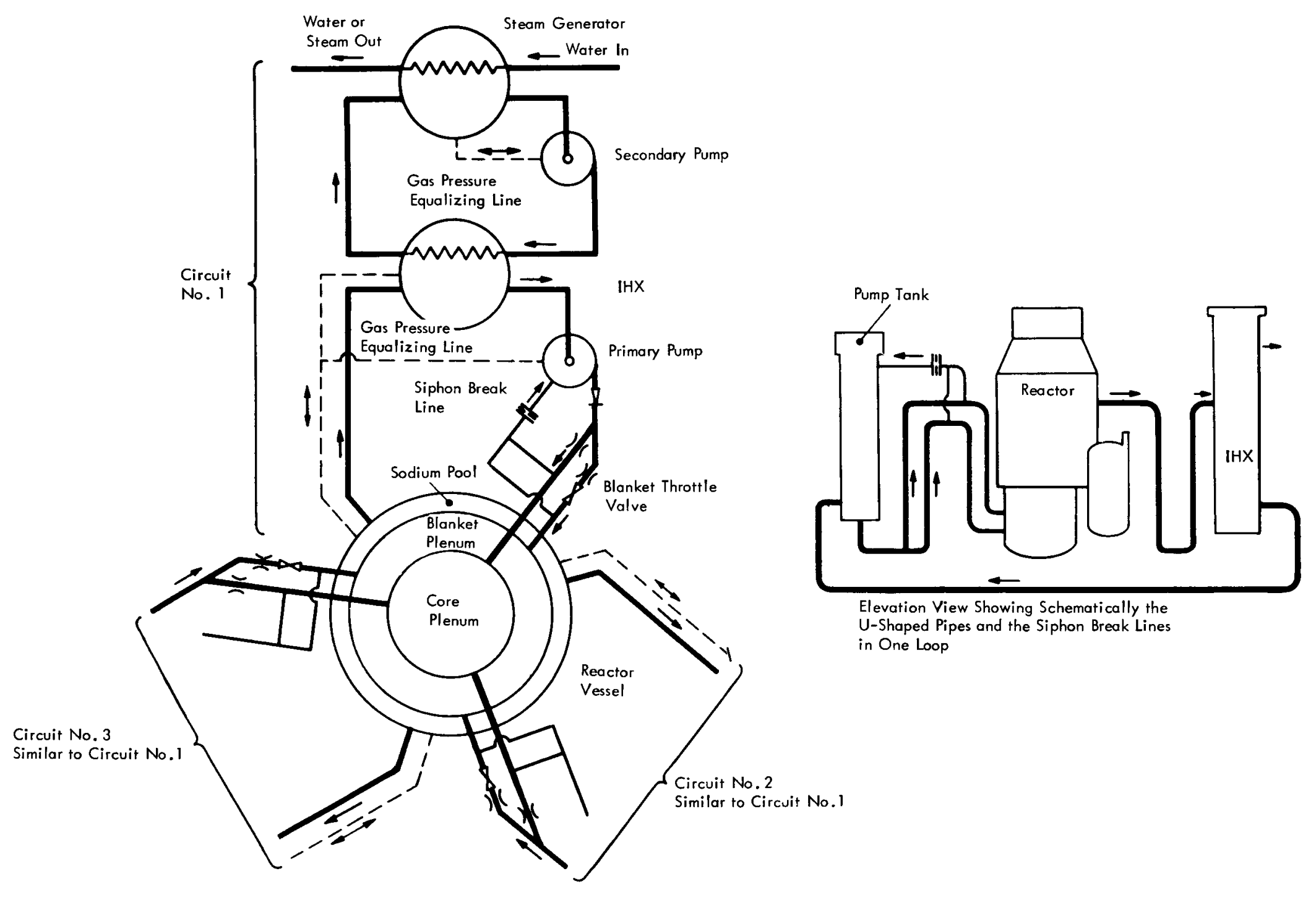

FIG. 2 HEAT REMOVAL SYSTEMS 
B. REACTOR VESSEL INTERNAL STRUCTURES

The reactor cross sectional view, Fig. 3, indicates the placement of components within the reactor vessel. A total of 149 central lattice positions are occupied by core and IRB subassemblies, the antimony-beryllium neutron source, and ten operating control rod and safety rod channels. The ORB lattice positions surrounding the IRB comprise the outer blanket region and form an annulus whose top and bottom are at the same elevation as the top and bottom of the IRB. Surrounding the ORB are lattice positions containing stainless steel subassemblies which provide thermal and neutron shielding for the reactor vessel. The vessel exterior is surrounded by borated and nonborated graphite neutron shielding, all of which is contained inside the reactor primary shield tank.

Control rods and safety rods are of the poison type, containing boron carbide in which the boron is enriched in B-10. Provisions are made for eight safety rods and two operating control rods; one is for shimming and the other is for regulating. The two rods have a total control reactivity worth of 92 cents. Each safety rod has a worth of more than one dollar.

Neutron detectors (fission and ionization chambers) monitor reactor power for control and safety purposes and are located in six neutron-counter tubes embedded in the graphite neutron shield surrounding the reactor vessel. Eleven channels of nuclear instrumentation are used to monitor the full range of flux level encountered in operations and they provide redundancy for safety.

The rotating shield plug supports the HDM, the overhead handling mechanism (OHM), and the operating rod and safety control rod drives. The shield plug contains shielding materials of borated graphite and stainless steel. By rotating both the plug and the OHM (which is mounted eccentrically in the plug) all subassemblies can be loaded in or from the transfer rotor.

\section{PRIMARY SODIUM COOLANT SYSTEM}

Sodium flow in each of the three parallel primary coolant loops is directed from the discharge end of the primary pump through a 16-in. reactor supply line. A tee diverts the sodium into 6- and 14-in. lines which feed the high- and low-pressure plena. Electromagnetic flowmeters having permanent field magnets a re installed on both lines. A blanket throttle valve mounted in each 6 -in. line controls relative flow rates in the high- and low-pressure plena. The location of equipment is depicted in Fig. 4 .

Sodium pumped upward through the reactor subassemblies reaches a common pool in the upper reactor vessel. Coolant level is maintained a 


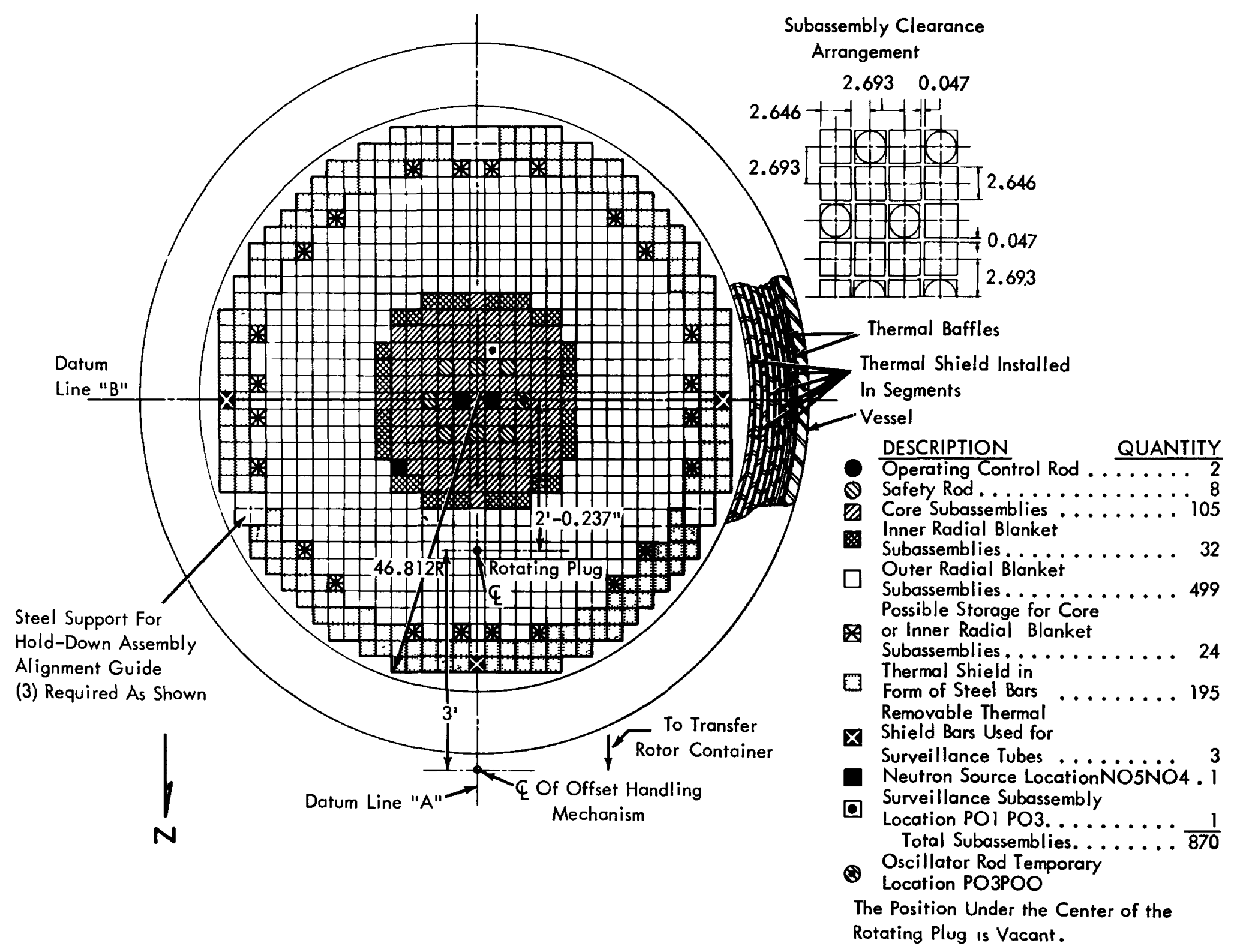

FIG. 3 REACTOR CROSS SECTION 


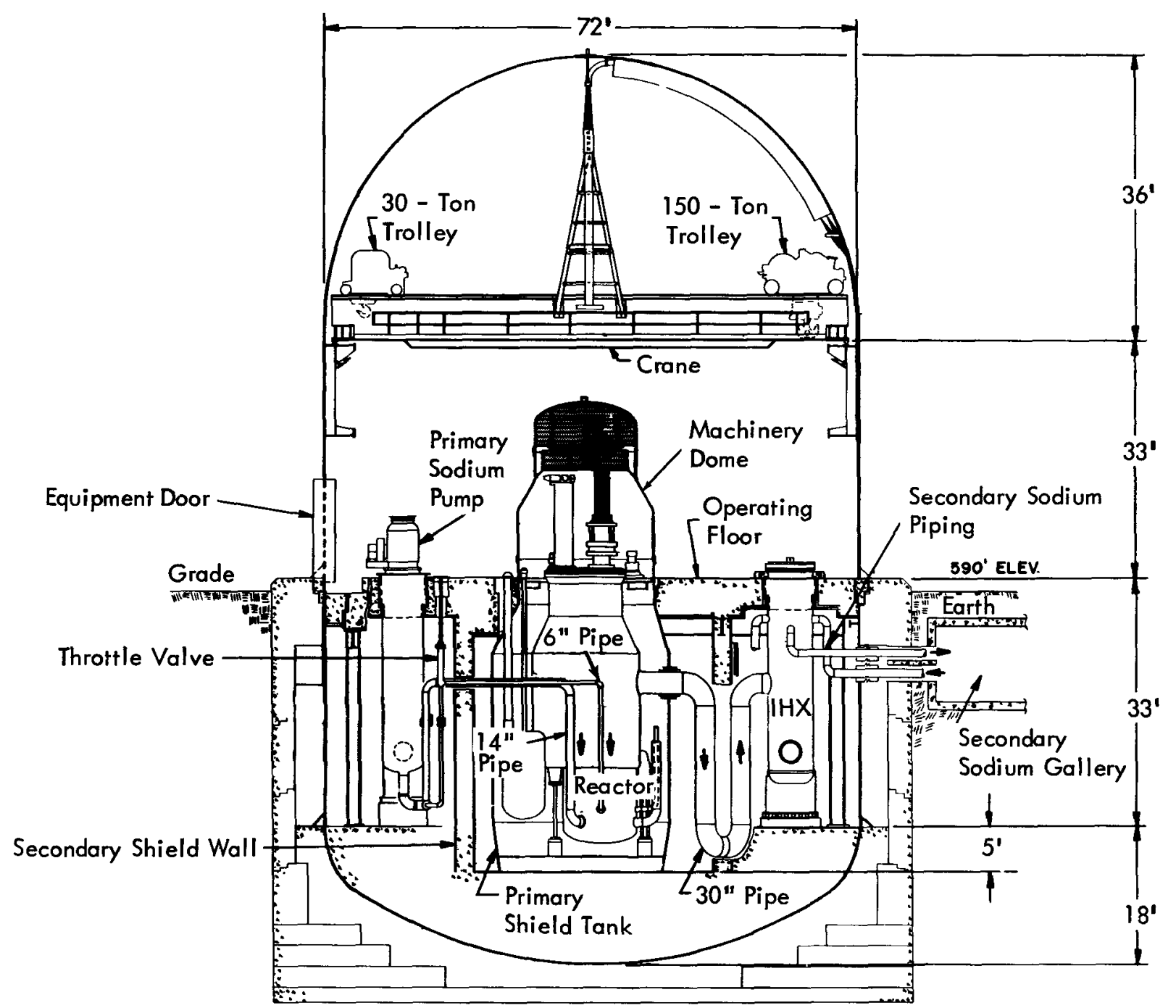

FIG. 4 ELEVATION OF REACTOR CONTAINMENT VESSEL 
few feet above the top of the 30-in. outlet lines and it is also maintained above the bottom surface of the rotating shield plug by a primary overflow system connected to the vessel through the 6 -in. overflow line. Sodium is gravity-fed through each 30-in. line to the shell side of the heat exchanger (IHX). It is a counter-flow, shell-and-tube-type unit in which primary sodium flows circumferentially around the shell and radially inward before passing downward. Baffles and cylindrical flow directors assist in achieving the desired flow pattern.

From each IHX the cooled sodium drains by gravity through a 30 -in. pipe to the primary sodium pump tank. A vertical shaft, single-stage centrifugal pump is mounted in the tank with a check valve at the discharge (bottom) end to prevent back-flow of sodium in a shut-down loop. The three primary pumps are driven by $1000 \mathrm{hp}, 4800$ volt, 3-stage motors; sodium flow rate is controlled by varying the pump motor speed. Continuous variable control is provided by a liquid rheostat in the rotor electrical circuit.

The entire primary system is contained within the primary shield tank in an oxygen-depleted atmosphere. Energy to maintain sodium in a liquid state during reactor shutdown is supplied by induction and resistance heaters to pipes and critical areas in other equipment. An oxygen-depleted atmosphere is maintained under the floor of the reactor building and it is cooled by the below-floor ventilation system which employs an external water-cooled heat exchanger. A separate cooling and heating system controls the above-floor atmosphere.

In addition to maintaining a proper coolant level in the reactor, the primary overflow system supplies sodium to the primary sodium service system. Sodium purification cold trap, hot trap, and a plugging indicator are among the systems provided which operate off the overflow line. An inert gas system supplies an argon blanket over the coolant surfaces in the overflow system, reactor, IHX, pumps, and elsewhere. More details of the primary system and descriptions of pipe and other thermal insulation and safety systems (to detect leaks, prevent losses of coolant, provide emergency cooling, etc.) will be found in Reference 1.

\section{SECONDARY SODIUM AND FEEDWATER- STEAM COOLANT SYSTEM}

The three secondary coolant loops are independent and they have separate sodium fillings. In each loop, sodium flows into the reactor building and upward (counterflow) on the tube side of the IHX. Pipes of 12 -in. and 18-in. diam then carry the heated sodium underground out of the reactor building to the steam generator building where the coolant enters the shell side of the steam generator. The steam generator is a vertical, once-through unit, in which the sodium enters at the top, flows down- 
ward over the serpentine water-steam tubes, and exits at the bottom to the pump. The adjacent, vertically mounted, circulating pump, driven by a $350 \mathrm{hp}, 900 \mathrm{rpm}$ induction motor, draws the sodium through its inlet at the bottom of the pump and exhausts it to an 18-in. pipe for the return to the reactor building. Control of pump speed is achieved by control of the field excitation of an eddy current coupling. Induction heaters a re used on portions of the pipes. An electromagnetic flowmeter and an independent a rgon cover gas system are provided in each secondary loop. A single sodium service system is capable of being connected to any one of the three secondary loops.

Feedwater is supplied to the three steam generators from the common No. 4 heater and storage tank through T-separations to individual lines in which are mounted the feedwater pumps. In each loop the water flows from the pumps through pipes to the nozzles of calibrated flowmeters, then into the header ring of the steam generator, and downward through the straight vertical tubes clustered in the shrouded area in the center of the generator shell. From there it passes upward through the horizontal U-tube serpentine sections in the cross-and counter-flow region to a steam header region. Steam outputs are fed to a common line which can transfer the steam to the 150-Mwe, tandem-compound, single-flow turbine generator or it can return the steam to the No. 4 heater by means of condenser pumps, the reby conserving the filtered and deionized feedwater.

Equipment is supplied to provide emergency and temporary cooling of the reactor system, including afterheat removal during repair or complete loss of externally supplied electrical power. Other systems provide for safety and increased efficiency. They include a rupture disk to release pressures in the steam generator as a result of a sodium-water reaction, reheating of steam between turbine stages, feedwater mockup and preheat equipment, and others.

\section{E. MODE OF OPERATION}

Normal plant operation is planned for full (three-loop) operation. An alternate mode of operation with two loops has been designed and such runs were scheduled and performed as part of the nuclear testing program. Operational procedures during start-up and nominal values for three-loop, 200-Mw operation are given here as an outline of normal operation. Detailed description of planned operations can be found in Reference 1 . Normally, the blanket throttle valve is set so that about 85 per cent of the primary system sodium flow (three-loop operation) is allowed through the core and intermediate blanket region. Reactor system temperature is adjusted to $517 \mathrm{~F}$ by varying the very low feedwater flow rate $(340 \mathrm{~F})$ into the flooded steam generators. In preparation for start-up, the flow of each primary and secondary loop is adjusted by varying pump speed to obtain the desired loop flow rate of sodium, normally $2.9 \times 10^{6} \mathrm{lb} / \mathrm{hr}$. Below- 
floor cooling, sodium transit pipe electrical heaters, and the performance of primary system overflow and cold-trap purification are adjusted for desired operation. Outlet values are programmed to maintain a pressure of $950 \mathrm{psi}$ in the bypass steam line. Safety rods are then withdrawn in steps to ensure that the reactor will be subcritical with all safety rods fully withdrawn. Criticality is reached by withdrawal of the control rod. Approach to power requires continuous withdrawal of the control rod to provide temperature override; this can be done manually or by the automatic control system which operates from examination of reactor outlet temperature. A nominal value of $1.2 \mathrm{~F}$ per min or less is maintained for reactor temperature change. The secondary sodium outlet temperatures of the steam generator are maintained at $517 \mathrm{~F}$ by control of feedwater flow rates. Here, automatic and manual controls are also available. The outlet steam of the steam generator becomes saturated at about $80 \mathrm{Mw}$ and thereafter outlet temperature begins to rise with further power increases. Steam can be transferred to the main steam line at about $100 \mathrm{Mw}$. Steam pressure can then be changed from 950 psia (a value chosen for increased stability in the low power ranges) to 600 psia. The turbine can then be loaded, if desired, and power can be increased to the desired level where flow, power, and temperatures are stabilized. Flows and temperatures expected for 200 $\mathrm{Mw}$ are listed below. They are based on design studies; actual values are expected to be somewhat different.

Flow Rate, $10^{6} \mathrm{lb} / \mathrm{hr}$ Hot Leg Temperature, F Cold Leg Temperature, F

* at reactor outlet

$\dagger$ at steam generator inlet
Steam-Feedwate $r$

$\begin{array}{cc}\begin{array}{c}\text { Primary } \\ \text { System }\end{array} & \begin{array}{c}\text { Secondary } \\ \text { System }\end{array} \\ 8.9 & 8.9 \\ 800 * & 767 \dagger \\ 550 & 517\end{array}$

System at 600 psia

0.64

764

340 
- 


\section{DESCRIPTION OF TESTS}

Reactor power is one of the important quantities that must be determined for the Enrico Fermi Reactor. It is required in shielding and activa tion physics measurements, power coefficient of reactivity, plant thermal study and other investigations. Some safety limits also require knowledge of the power for optimum interpretation. Calibration experiments were therefore included in the Fermi test schedule and appropriate methods and plant characteristics were surveyed. Two independent measurement techniques were selected. A nuclear calibration was performed ${ }^{2}$ at low powers using a neutron counter of known detection efficiency and measured reactor fission rate distributions. The probable error in the resultant low-power calibration was found to be 8 per cent. Extrapolation of the calibration to high powers also requires that nuclear detector linearity be known over the range of extrapolation.

Determination of thermal power output was chosen to compliment the information from the nuclear test and also to provide an independent and more accurate measurement. Heat balance experiments were conducted which required the reactor to be operated at stable high-power levels with flows and temperatures held constant. Under these conditions, the power transferred from reactor to primary coolant, from primary to secondary coolant, and to the steam-producing system were equal, except for very small differences. Extraneous sources (e.g., coolant pumps) and sinks (e. g. , dissipative heat losses to the surroundings) required minor corrections.

Measurements from which thermal output could be calculated could be taken from any of the three heat transfer circuits, primary sodium loop, secondary sodium loop or feedwater-steam coolant loops. Measurements from the feedwater-steam system loops were chosen for the power calibration to avoid the large error that would be introduced by the readings from the electromagnetic sodium flowmeters. These water flow rates could be accurately determined by use of calibrated water-flow nozzles. Further advantages accrued from the accessibility of the loops for removal of the nozzles for pretest inspection and for insertion of high-reliability temperature detectors. Reactor power would then be accurately determined at powers sufficient to generate superheated steam. Measurement of steam temperature and pressure at a power level greater than about $80 \mathrm{Mw}$ (for three coolant loops under normal operating conditions) would singularly determine steam enthalpy. 
The test program consisted of three sets of experiments. First, a comparison of reactor temperature detector readings was made under isothermal conditions at zero-power. Individual detector corrections were obtained for application in the power calibration. The temperature range corresponded to that of the high-power tests. A second set of is othermal tests was made to determine the only extraneous power source that could not be sufficiently well estimated from available data. Losses through dissipative heat transfer to regions surrounding the system were measured by reducing all the potential contributions from all other sources as much as possible, e. g., the reactor was shutdown and the steam generators were drained. The third set was a series of three heat balance tests in the range between 90 and $100 \mathrm{Mw}$ and under essentially normal three-loop operational conditions. These tests were performed with the use of temperature detectors that monitored feedwater inlet temperature and steam outlet temperature for each of the three steam generators. Water flow rates were determined from meas urement of pressure drop across the terminals of flowmeter nozzles in the steam generator feedwater supply lines. The nozzles had been calibrated before installation. Corrections were made for extraneous sources including the measured dissipative losses, and reactor power was obtained.

Since other operational priorities precluded exclusive use of the core for these tests, the test conditions were somewhat different than desired. The effects were taken into account in the overall error analys is and estimates were made of the ultimate limit in test accuracy. 


\section{TEST INSTRUMENTATION AND EXPERIMENTAL PROCEDURES}

Most of the instrumentation used in the heat balance tests was available as plant operational equipment. Two additions were made to permit more accurate measurements. Experimental thermocouples of high precision were installed to monitor the temperatures of steam generator sodium and the inlet and outlet water. Manometers were installed at the flow nozzles to measure water flow rates in the feedwater lines. Three series of tests were performed: (1) various test and plant temperature detectors were compared, (2) dissipative heat losses of the system were determined, and (3) at-power heat balance tests were performed.

\section{A. TEST INSTRUMENTATION}

\section{Temperature Detectors}

Calibrated temperature detectors were installed in the inlets and outlets of the sodium and feedwater-steam pipes to each steam generator. Four iron-constantan thermocouples were installed in Loop 1:

\begin{tabular}{ccc}
$\begin{array}{c}\text { Location At } \\
\text { Steam Generator }\end{array}$ & $\begin{array}{c}\text { Type Of } \\
\text { Installation }\end{array}$ & Designation \\
\cline { 2 - 2 } & Pipe Wall & TE (Na In)-1 \\
$\mathrm{Na} \mathrm{Inlet}$ & Pipe Wall & TE (Na Out)-1 \\
$\mathrm{Na}$ Outlet & Well & TE (FW)-1 \\
Feedwater Inlet & Well & TE(S) -1 \\
Steam Outlet & &
\end{tabular}

Similarly, four other thermocouples with corresponding designations were installed in each of the other two loops. All were monitored on a multipoint potentiometer; cold junctions for the thermocouples were established in an ice bath. Before installation, detector calibrations were made at the research laboratories of the Detroit Edison Company. Each detector was mounted in a monitored experimental bath and indications were recorded at four temperatures between 500 and $800 \mathrm{~F}$. Deviations from that of a standard temperature device did not exceed $2 \mathrm{~F}$.

Plant temperature detectors used in the tests included the ironconstantan thermocouples (TC) and platinum resistance temperature detectors (RTD) shown in Table 1 . 
TABLE 1 - PLANT TEMPERATURE DETECTORS

\begin{tabular}{|c|c|c|c|}
\hline Designation & Type & Monitors & Location \\
\hline$T E 209-1 *$ & RTD & $\begin{array}{l}\text { Reactor Inlet } \\
\text { Sodium }\end{array}$ & 6-in. Blanket Sodium Inlet Lines \\
\hline $\begin{aligned} \text { TE } 115-9 \\
\\
-26 \\
-31 \\
-33\end{aligned}$ & TC & $\begin{array}{l}\text { Four Core Sub- } \\
\text { assembly Outlets }\end{array}$ & $\begin{array}{l}\text { Holddown Finger, Over Subas - } \\
\text { sembly Sodium Outlet }\end{array}$ \\
\hline TE $133-7$ & $\mathrm{TC}$ & $\begin{array}{c}\text { One IRB Subas - } \\
\text { sembly Outlet }\end{array}$ & \\
\hline TE $217-1 *$ & $\mathrm{TC}$ & Reactor Outlet & 30-in. Outlet Pipe \\
\hline TE $201-1 *$ & RTD & Reactor Outlet & 30-in. Outlet Pipe \\
\hline TE $308-1 *$ & RTD & $\begin{array}{l}\text { Steam Generator } \\
\mathrm{Na} \text { Inlet }\end{array}$ & Steam Generator Na Supply Line \\
\hline TE $301-1 *$ & $\mathrm{TC}$ & $\begin{array}{l}\text { Steam Generator } \\
\mathrm{Na} \text { Outlet }\end{array}$ & Steam Generator $\mathrm{Na}$ Outlet Line \\
\hline
\end{tabular}

* Last number indicates detector is in Loop 1. Similar installations are available in each of the other loops.

A potentiometer bridge and Wheatstone bridge provided accurate readout of the detector outputs. Cold junctions for the thermocouples were at ambient temperature in the reactor control room. Ambient temperature was monitored and corrections for any changes were made.

\section{Manometers and Flow Nozzles}

The other special instruments provided for the tests were three single tube (Meriam Instrument Co. Model 30FA200) or well-type, highpressure manometers corrected for finite dimensions of the wells. These were located in the steam generator room and they were connected to taps at calibrated flow nozzles in the water supply lines of the steam generator. The connection lines were water-filled. The liquid used in the manometer was tetrabromoethane, which has a density, $\rho(1 \mathrm{~b} / \mathrm{ft})^{3}$, at a temperature, $T(F)$, of: 


$$
\rho=184.88-0.774(T-20)
$$

for $T$ in the range of 70 to $120 \mathrm{~F}$.

The flow nozzles are the ISA type, made of type 304 stainless steel; the diam of the inlet side is $5.831 \mathrm{in}$. and the throat diam is $3.534 \mathrm{in}$. Calibrations had been made at Ohio State University where it was found that all measured discharge coefficients were within 0.5 per cent of unity. Installations at Fermi were made such that straight sections of feedwater pipe, 17 - ft and 4-ft long, preceeded and followed the nozzles, respectively. Shortly before the tests began the nozzles were removed and inspected and were found to be in excellent condition.

\section{Monitors of Neutron Level, Flow, and Auxiliary Systems}

Reactor neutron level was monitored by several nuclear-leakage detectors whose outputs were expected to be linear with power (see Appendix A). Each of the pertinent neutron-sensitive detectors is an ionization chamber lined with boron enriched in B-10, located in the graphite shielding outside the reactor. The output of one of the detectors was connected to a micromicroammeter (Keithley Co. Model 415), designated detector system ND-1. Five plant operational detectors, designated as PR-1 through PR-5, were connected to current amplifiers with linea $r$ readout provided on a multipoint electronic recorder in the reactor control room.

Instruments to monitor primary and secondary sodium flow rates consisted of nine electromagnetic-type flowmeters employing permanent magnets. Separate instruments were provided in the 6-in.-diam reactor blanket inlet line, the 14-in. core inlet line, and the secondary sodium line. While the measurements were essentially repeatable, flow calibration was known to be unreliable.

During the tests, the pump speed and power input of the primary and secondary sodium loops were measured. Tachometer-generators provided output pulses from each pump proportional to pump speed; the pulses were fed to an electronic scaler. Input power to the pumps was measured with standard electrical wattmeters connected across electrical taps provided at the input side of each pump motor.

Two auxiliary heat exchanger systems were operated and monitored during most of the tests. The heat removal rate of the below-floor cooling system was determined from: (1) temperature detectors which monitored the below-floor gas temperatures of the exchanger inlet and outlet, and (2) a manometer from which gas flow rate was determined. The primary sodium cold trap system for purifying the sodium was also monitored, when operating, for heat removal rate by use of instruments similar to those in the below-floor system. 
The locations of most of the instruments used in these tests are shown schematically in Fig. 5 for the reactor and for one of the three coolant loop systems. These systems have identical instrumentation.

\section{B. EXPERIMENTAL PROCEDURES}

\section{Temperature Detector Comparisons}

Because of the importance of temperature measurements in the tests and because the plant temperature detectors had been installed for eight years, a test was performed to compare readings of all temperature detectors to be used in the heat balance test. The tests were conducted during one of the dissipative heat loss tests when reactor power was zero and the water side of the three steam generators was filled with nitrogen. Further, because of operational requirements, secondary sodium Loop 1 was also drained and filled with nitrogen. System temperature was stabilized at $522 \pm 2 \mathrm{~F}$ by varying the pump speed and thus power input to the sodium. Readings were taken in $10-$ min periods at hourly intervals. All available useful primary and secondary detectors were monitored. The test extended over a 9-hr period during which the average temperature drift did not exceed $0.5 \mathrm{~F} / \mathrm{hr}$. At the end of the period, reactor and pump power were employed to increase the system temperature to about $650 \mathrm{~F}$. Following elimination of reactor power and the stabilization of system temperature by pump speed, temperature was again monitored for an 8-hr period. The indicated sodium temperature was $657 \pm$ $1 \mathrm{~F}$, and the drift rate did not exceed $0.9 \mathrm{~F} / \mathrm{hr}$.

Differences in indicated temperatures were to be expected among all the detectors. Further, since their effective operational ages were the same, it was assumed that no single indication would be any more reliable than another. In some cases, a particular device had readings which were noticeably deviant or erratic; so those readings were rejected. Comparisons were then made among the remaining instruments, with particular emphasis given to the consistency of the difference among various detectors. Feedwater system detectors could not be examined because of the ambivalent nitrogen temperature.

\section{Dissipative Heat Losses}

The purpose of the heat balance tests was to relate the power measured at the water-side terminals of the steam generators to the nuclear power generated in the reactor. This required consideration of all secondary power sources and sinks so that:

$$
\mathrm{P}_{\mathrm{R}}+\Sigma \mathrm{P}_{\mathrm{Sec}}=\mathrm{P}_{\mathrm{W}}
$$




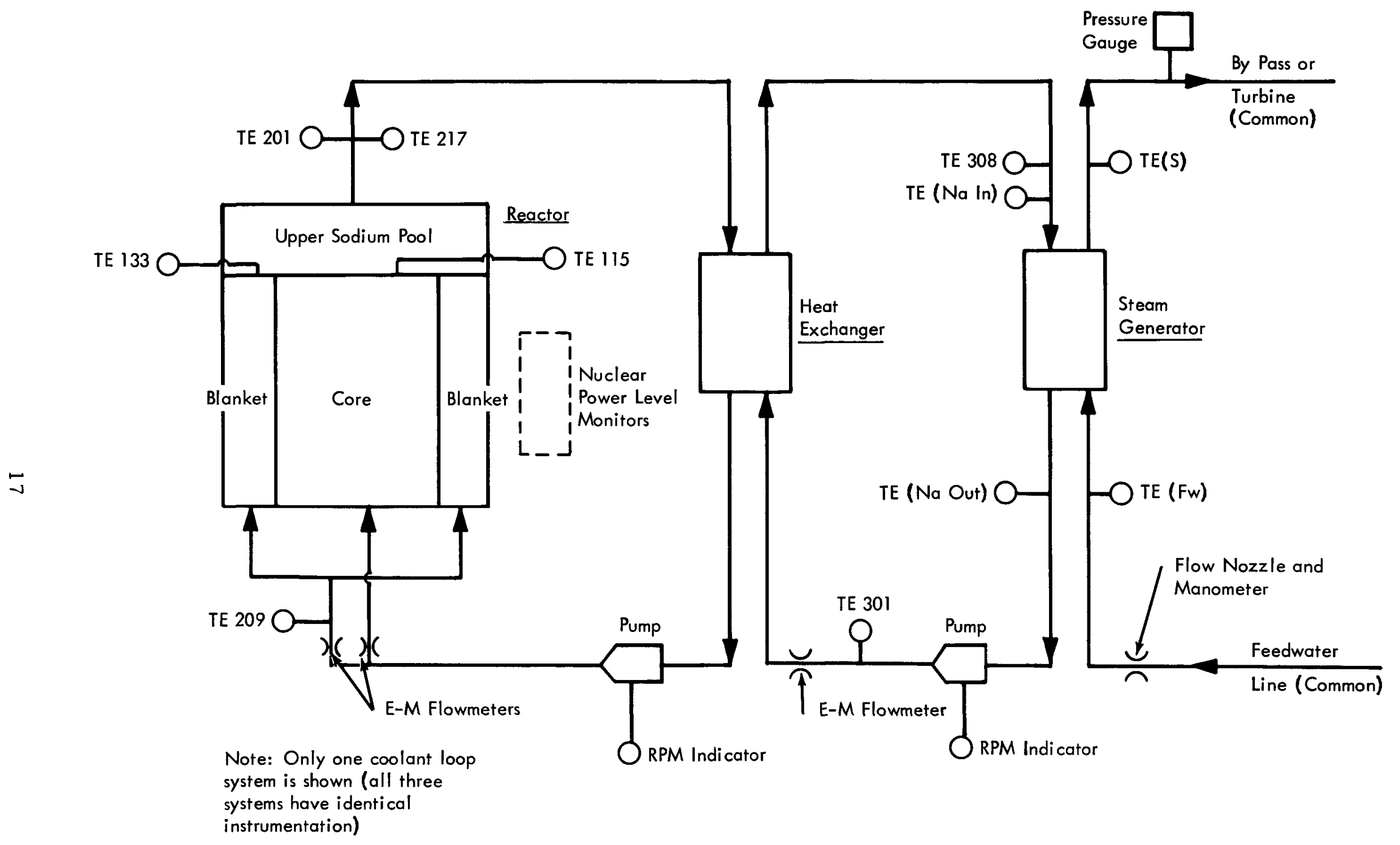

FIG. 5 LOCATION OF INSTRUMENTS USED IN TESTS 
where, for these tests:

$$
\Sigma P_{\text {Sec }}=P_{p}+P_{H}-P_{C T}-P_{O V}-P_{C}-P_{H L}
$$

where,

$$
\begin{aligned}
\mathrm{P}= & \text { power } \\
\mathrm{R}= & \text { reactor } \\
\mathrm{W}= & \text { measured at the water side of the steam generators } \\
\mathrm{Sec}= & \text { secondary sources: } \\
\mathrm{P}= & \text { pumps } \\
\mathrm{H}= & \text { heaters } \\
\mathrm{CT}= & \text { cold trap } \\
\mathrm{OV}= & \text { dissipative losses in the primary overflow system } \\
\mathrm{C}= & \text { heat removed by the below -floor cooling system } \\
\mathrm{HL}= & \text { dissipative losses to regions surrounding the } \\
& \quad \text { primary and secondary sodium systems }
\end{aligned}
$$

One secondary power source, $P_{H L}$, could not be satisfactorily estimated from direct measurements. It was therefore determined in a series of tests designed for the purpose. For given ambient conditions, the losses, $P_{H L}$, are a function of reactor system temperature only. Therefore, $P_{H L}$ can be satisfactorily determined from Eqs. (2) and (3) if large terms such as $P_{R}$ and $P_{W}$ are reduced to zero. Additionally, if the effects of other secondary sources are minimized, greater accuracy of the $P_{H L}$ measurement will result. Ideally, all secondary service systems and heaters would be shut down so that the pumps would consititute the only power source, or:

$$
P_{H L}=P_{p}
$$

under steady-state, isothermal conditions. However, plant operating conditions require operation of the below-floor cooling system and some of the electrical heaters. The conditions of these experiments were, therefore:

- The reactor was shut down $\left(P_{R}=0\right)$

- Specified heaters were left on

- The cold trap and overflow system was shut down $\left(\mathrm{P}_{\mathrm{CT}}=\mathrm{P}_{\mathrm{OV}}=0\right)$

- The steam generator water sides were boiled dry, capped, and filled with nitrogen $\left(P_{W} \approx 0\right)$ 
- The below-floor system was operated under normal conditions (as it was for all the heat balance tests).

- The system was brought to is othermal conditions by adjustment of pump speed; e.g., by power input to the sodium.

Under these conditions, Eqs. (2) and (3) reduce to:

$$
\mathrm{P}_{\mathrm{HL}}=\mathrm{P}_{\mathrm{p}}+\mathrm{P}_{\mathrm{H}}
$$

where $P_{H L}(\mathrm{kw})$ is determined for the system temperature and the number of operating coolant loops used in the test.

Power supplied to the coolant from each sodium pump was determined by measurement of power input to the pump motor and consideration of motor and drive characteristics. Heat input to the sodium by the pumps, $P$, was derived from:

$$
P_{p}=E_{W M} m \mathrm{~N} / \mathrm{No}
$$

where,

$$
\begin{aligned}
\mathrm{E}_{\mathrm{WM}}= & \text { total electrical power }(\mathrm{kw}) \text { supplied to the pump motor, } \\
& \text { measured by wattmeters } \\
\mathrm{m}= & \text { pump motor efficiency, supplied by the vendor } \\
\mathrm{N} / \mathrm{No}= & \text { efficiency of the speed reduction system ( } \mathrm{rheostat})= \\
& \text { ratio of pump speed }(\mathrm{r} \mathrm{pm}) \text { to no-load speed }(900 \mathrm{rpm} \\
& \text { for the primary and } 880 \mathrm{rpm} \text { for the secondary pumps). }
\end{aligned}
$$

Coolant-pipe heater power was obtained from individual circuit currents measured with a clamp-on-type induction ammeter. It was assumed that 50 per cent of the measured heater power was transferred to the sodium.

General test procedure was to first establish the desired, or in cases where reactor schedule prevented it, somewhat compromised conditions. Reactor temperature was then stabilized at the existing value by variation of pump speed. After each change, the system was allowed to drift unchanged for a period of one or several hours depending on the rate of temperature change. Periodic measurements were then made of pump speed, power input, and heater currents and temperatures, using normal equipment. In some cases, several minor adjustments were required. Final measurements were taken when a satisfactory small drift rate had been established.

Three tests were run under acceptable conditions. All three loops were available for the first test and system temperature was stabilized at $530 \mathrm{~F}$. The second test was a two-loop test at $520 \mathrm{~F}$, designed to measure losses for those cases when one coolant loop is shut down. The third was an extended test of several days to measure losses at elevated temperatures, 
up to $657 \mathrm{~F}$. It was also a two-loop test imposed by the reactor schedule with one secondary sodium loop drained and filled with argon. (In addition, the test was used to examine temperature detector performance.) For the test, the reactor was operated at power levels up to $1.5 \mathrm{Mw}$, to reduce the time necessary to raise system temperature. Power was reduced to near zero during the period of stabilization and measurement.

Data were compiled and reduced for the periods of low drift rate. Pump and heater power were obtained as described. Power transferred to the feedwater system was assumed to be zero. Then, as shown in Eq. (2) and subsequently defined, heat losses were calculated as the sum of the power supplied by the heaters and pumps. A drift rate correction was made using a value for total system heat capacity of $110 \mathrm{kw} / \mathrm{F} / \mathrm{hr}$, obtained from the tests during periods of constant drift rate.

\section{Heat Balance Experiment}

Heat balance tests were conducted at three power levels and on two different days with all coolant loops operative. Because the plant operational schedule required other tests and demonstrations to be run concurrently, optimum conditions for the experiments were not achieved. How ever, sufficient data were obtained from enough of the desired instruments to achieve a final power calibration.

The following procedure was followed for each test day. Before beginning the run, system sodium temperature was stabilized by adjustment of pump power input to the coolant. Since sodium flow rates at or near operational level were being maintained, pump power input exceeded dissipative losses and some water flow was required to maintain system temperature level. As much time as was then available was used in recording sodium temperature detector readings to corroborate the established zero corrections and demonstrate reliability. Zero readings were taken on the nuclear power detectors and on the manometers using a system of isolation valves. Undesired pipe heater circuits were turned off and normal operation of the below-floor cooling was verified. Operation of the primary cold trap was required during these tests which,in turn, required operation of the primary overflow system.

Final adjustments in primary and secondary flow rates were made before start-up of the reactor. Flow values and pump speeds were recorded. Thereafter, the reactor was brought to the desired power level by normal procedures (Section I). Temperature and power detectors were monitored every $30 \mathrm{~min}$, or more frequently when desired.

Normal procedures were used to stabilize power level at the selected test power. Adjustments in the manually controlled feedwater flow rates continued for some time, to stabilize steam gene rator outlet sodium 
temperature. A pause then followed during which no changes in operating conditions occurred. The pause was as long as possible, but could not always be of sufficient duration.

The data-taking period then began in which temperatures were taken. Continous individual manometer readings were taken by observing the fluctuating fluid level for $1 \mathrm{~min}$ and by recording the maximum and minimum values. One or two sets of nuclear-level detector readings and flow readings were also taken during the period. When possible, concurrent readings were of pump power input, below-floor cooling data, and pipe heater currents. Data for steam pressure and ambient temperature for the manometer were also taken.

Basically, the Fermi reactor is a stable system (heavily fedback). It was therefore quite easy to achieve stable levels in power, flow, and temperature. For example, periods of 15-30 min in which no system adjustments were required to stabilize system variables were common. Minor long term drifts were more likely to result from independent cir cumstances, e.g., from a change in flow caused by variation in the nominal 4800-volt motor supply voltage. Therefore, the limits to stability demonstration were usually caused by the schedule-limited access time to the reactor. Estimates of pertinent times, levels, and time periods for the three tests identify the major characteristics of the tests; they also provide at least a qualitative measure of the reliability of each. These data are summarized in Table 2.

TABLE 2 - OPERATIONAL SUMMARY HEAT BALANCE TESTS

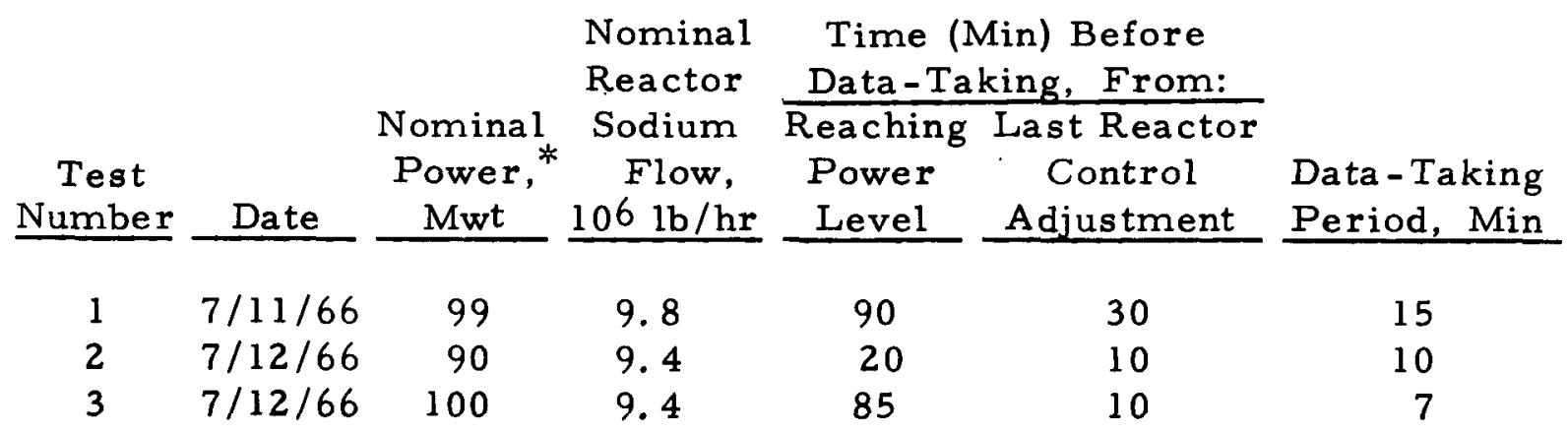

* Based on nuclear calibration of ND-1 detector 
Data were reduced to single ralues for each quantity observed by averaging individual readings over the full data-taking period. Error estimates discussed in a later section are, in part, based on examination of individual variations. Power was calculated from the following generalized equation.

$$
P_{R}=C_{0} \sum_{i=1}^{3} \Delta H_{i} Q_{i}+C
$$

where,

$$
\begin{aligned}
P_{R}= & \text { reactor power, } M w \\
C_{0}= & \text { conversion factor, Btu/hr to } \mathrm{Mw} \\
\Delta \mathrm{H}_{\mathbf{i}}= & \begin{array}{l}
\text { enthalpy difference across terminals of steam genera- } \\
\text { tor } \mathrm{i}, \text { per unit mas of water, Btu } / \mathrm{b}
\end{array} \\
\mathrm{Q}_{\mathbf{i}}= & \text { feedwater flow rate through steam generator, } 1 \mathrm{~b} / \mathrm{hr} \\
\mathrm{C}= & \text { corrections, } \mathrm{Mw}, \text { for the extraneous effects of dis - } \\
& \text { sipative heat losses; pump, heater, and cold trap } \\
& \text { operation; and system imbalance. }
\end{aligned}
$$

Enthalpy for steam and feedwater as a function of temperature and pressure was obtained from standard tables 3 . The equation for water flow rate is derived from basic considerations:

$$
Q(l b / h r)=\frac{3600 C_{q}^{A} N}{\sqrt{1-A_{N}^{2} / A_{p}^{2}}}\left\{2 h\left[\rho_{M}\left(T_{A}\right)-p_{W}\left(T_{A}\right)\right] \gamma\left(T_{w}\right) g\right\}^{1 / 2}
$$

where,

$$
\begin{aligned}
& C_{q}=\text { coefficient of discharge }=1.005 \text { (see Section III-A -2) } \\
& A_{N}=\text { inside area of nozzle (downstream end), } \mathrm{ft}^{2} \\
& A_{p}=\text { inside area of pipe (nozzle upstream end), } \mathrm{ft}^{2} \\
& \mathrm{~h}=\text { measured height of manometer fluid, ft } \\
& \rho_{M}\left(T_{A}\right)=\text { density of manometer fluid, tetrabromoethane, at ambient } \\
& \text { temperature, } T_{A} \text {, in steam generator room, } 1 \mathrm{~b} / \mathrm{ft}^{3} \\
& \mathrm{P}_{\mathrm{W}}\left(\mathrm{T}_{\mathrm{A}}\right)=\text { density of water at ambient temperature } \mathrm{T}_{\mathrm{A}}, \mathrm{lb} / \mathrm{ft} \mathrm{t}^{3} \\
& \gamma\left(T_{w}\right)=\text { density of water at feedwater temperature } T_{w}, 1 b / f^{3} \\
& g=\text { gravitational acceleration, } 32.17 \mathrm{ft} / \mathrm{sec} / \mathrm{sec}
\end{aligned}
$$


A system temperature equal to the average of the system inlet and outlet temperatures was used for determining the heat loss correction. This correction was derived from the three-loop curve of Fig. 6. The correction procedure for pump and heater is described in Section III-B-2. Cold trap corrections were based on known normal operating parameters. Corrections necessary for power removed from the reactor by neutron and gamma escape fluxes were found from calculations to be much less than 1 per cent of reactor power; these were ignored. 


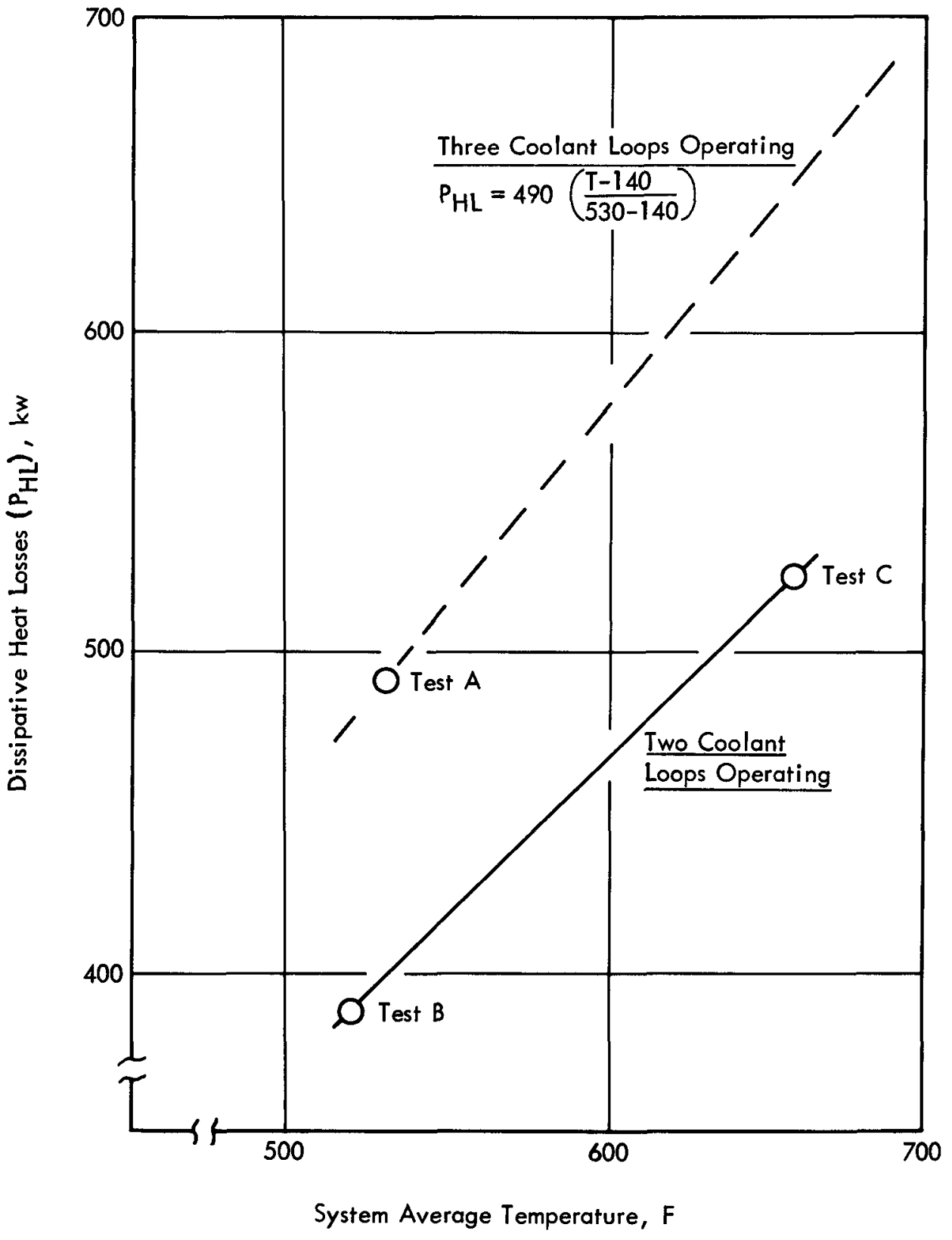

FIG. 6 DISSIPATIVE HEAT LOSSES 
IV. TEST RESULTS

\section{A. TEMPERATURE DETECTOR ISOTHERMAL COMPARISONS}

It was intended to evaluate temperature detector performance over a period of several years by incorporating with these tests the results from the manufacturer's calibrations prior to instrument installation and also the test data obtained from another isothermal comparison made in 1963. A chronological change was expected that would permit selection of reliable detectors and an evaluation of the reliability of the normal detectors. With the reduction of the several hundred headings taken during the current test as described here, it became apparent that the detectors were of sufficient reliability to obviate the earlier and generally less consistent results. In particular, several sets of manufacturer's corrections based on laboratory bath experiments exhibited very little consistency with the isothermal tests. It was possible (having assumed that no detector reading would, per se, register true sodium temperature) to derive from the performance of the detectors a value of sodium temperature and the corresponding experimental error.

At each of the temperature levels obtained during the tests, and for each set of hourly readings, each thermocouple reading was converted without subsequent corrections to temperature by means of standard iron-constantan conversion tables. Resistance detector curves had been generated in the earlier isothermal tests. Each temperature was then compared to the average of the concurrent readings of four TE-115 detectors, selected to eliminate the effects of the small temperature drift rate because:

- Agreement among the four detectors was excellent.

- No overall systematic trends could be observed in the results.

It was believed that the excellent performance of the detectors was partially due to the extensive thermal contact with sodium afforded them by their position in the holddown fingers. Other detectors, primarily those in wells which are in the coolant pipes, exhibited somewhat less consistent response.

Differences between individual detector readings and the TE- 115 averages were obtained at both $522 \mathrm{~F}$ and $657 \mathrm{~F}$. Average values for each difference are listed in Table 3 for some of the most frequently used detectors which were available for the test.

The results exhibited excellent reproducibility from which a consistent pattern was interpreted to mean that most of the detectors studied pro- 


\section{TABLE 3 - TEST RESULTS - TEMPERATURE DETECTOR COMPARISON}

\section{Plant \\ Detector}

TE-

$115-9 *$

$-26 *$

$-31 *$

$-33 *$

$133-7$

$209-1$

$-2$

$-3$

$217-2$

$-3$

$308-2$

$-3$

Test

Detector

( $\mathrm{Na}$ In) -2

$-3$

(Na Out) -2

$-3$
Difference Between Average Detector Reading and Average Reading of Four TE-115 Detectors

At $522 \mathrm{~F}$

0

At $657 \mathrm{~F}$

0.5

0

$-0.4$

0

$-0.4$

$-1.8$

0.9

$-1.4$

0.8

$-1.4$

$-7.4$

$-1.1$

$-1.7$

$-14.8$

1.7

0 $\begin{array}{ll}-4.5 & -6.8\end{array}$

$-3.7$

$-5.5$

$-2.2$

$-4.4$

$-3.7$

$-5.7$

* Four detectors used as base 
duced normal and quite adequate response. Variations were ascribed to differences and occasional discrepancies in detector installation. An overall range of $\pm 0.3 \mathrm{~F}$ was found for the repeatability of the reliable detectors; this variation was assumed to be produced by system thermal drift, cold junction thermal stability, and experimental error.

Most individual detector responses, including those of all TE-115 detectors, were within the $+0.3 \mathrm{~F}$ range of agreement with the TE-115 average. Detectors installed in wells, TE-209, TE-217, and TE-308 series responded consistently low, up to about $3 \mathrm{~F}$. Two detectors, TE-217-2, and TE-308-2, deviated significantly more, which implied inferior thermal contact between detector and well walls. Steam generator sodium test thermocouples responded $4 \mathrm{~F}$ to $6 \mathrm{~F}$ low, which result was expected because of their installation on the pipe walls.

Corrections for use in subsequent measurements were generated from Table 3. Each detector was assumed to give error in readings only in the zero reading. Therefore, a correction equal in magnitude and opposite in sign to the average of the two listed values was applied at all temperatures*. Detectors not examined were assumed to be correctable if some performance data were obtained later and the correction implied was less than $5 \mathrm{~F}$. In spite of the success in deriving an explanation for most detectors, the prime test detectors and the feedwater and steam thermocouples could not be examined in this way. Corrections were the refore made by using some observations made during operations when water flow rates were at very low values, so detector readings were very near those of the sodium detectors. Correction values chosen were $+2 \mathrm{~F}$ for the feedwater detectors $T E(F W)-1$ $-2,-3$, and $+4 \mathrm{~F}$ for the steam monitors $T E(S)-1,-2,-3$. Because of the dissimilar loading of the steam detectors (mounted in wells) and the water detectors (mounted in the pipe walls) and the somewhat arbitrary temperature corrections, the error in corrected monitored temperature was assumed to be $+4 \mathrm{~F}$.

\section{B. DISSIPATIVE HEAT LOSSES}

Three tests were performed in evaluating losses as defined. All pertinent data are listed in Table 4. Test conditions including system temperature are listed together with pump speed, power, and heater-supplied power. Corrections are included for system temperature drift rate; they are based on a measured system heat capacity of $110 \mathrm{kw} / \mathrm{F} / \mathrm{hr}$ obtained by observing changes in drift rates from changes in system power input. The full system three-1oop loss at $530 \mathrm{~F}$ was obtained from Test A. Tests B and $C$ were primarily useful in establishing loss sensitivity to system temperature since they were performed when one secondary loop was gas-filled.

\footnotetext{
* In some cases, data from subsequent pretest trials were also employed.
} 
TABLE 4 - TEST RESULTS - DISSIPATIVE HEAT LOSS

\section{Primary and Secondary Pump Data}

\begin{tabular}{|c|c|c|c|c|c|c|c|c|c|c|c|}
\hline \multirow[b]{2}{*}{$\begin{array}{l}\text { Test } \\
\text { No. }\end{array}$} & \multirow[b]{2}{*}{$\begin{array}{c}\text { System Temp } \\
\text { and Conditions, F }\end{array}$} & \multirow[b]{2}{*}{$\begin{array}{l}\text { Loop } \\
\text { No. }\end{array}$} & \multicolumn{2}{|c|}{ Primary } & \multicolumn{2}{|c|}{ Secondary } & \multicolumn{2}{|c|}{$\begin{array}{l}\text { Power Input To } \\
\text { Sodium From }\end{array}$} & \multicolumn{2}{|c|}{ System Temperature Drift } & \multirow[b]{2}{*}{$\begin{array}{l}\text { Dissipative } \\
\text { Losses, kw }\end{array}$} \\
\hline & & & $\begin{array}{c}\text { Speed, } \\
\text { rpm }\end{array}$ & $\begin{array}{c}\mathrm{Na} \\
\text { Power, } \\
\text { kw }\end{array}$ & $\begin{array}{c}\text { Speed, } \\
\text { rpm }\end{array}$ & $\begin{array}{c}\mathrm{Na} \\
\text { Power, } \\
\text { kw } \\
\end{array}$ & $\begin{array}{c}\text { Pumps, } \\
\text { total, } \\
\text { kw } \\
\end{array}$ & $\begin{array}{c}\text { Heater, } \\
\text { kw }\end{array}$ & $\begin{array}{c}\text { Rate of } \\
\text { Temp Change, } \\
\text { F/hr } \\
\end{array}$ & $\begin{array}{c}\text { Correction, } \\
\mathrm{kw} \\
\end{array}$ & \\
\hline \multirow[t]{3}{*}{ A } & \multirow[t]{3}{*}{$\begin{array}{l}\text { All Loops } \\
\text { Operated At } 530 \mathrm{~F}\end{array}$} & 1 & 450 & 110 & 421 & 41 & & & & & \\
\hline & & 2 & 446 & 101 & 416 & 49 & 449 & 41 & $<0.2$ & 0 & 490 \\
\hline & & 3 & 452 & 109 & 405 & 39 & & & & & \\
\hline \multirow[t]{3}{*}{ B } & \multirow{3}{*}{$\begin{array}{l}\text { Two Primary } \\
\text { Loops Operated, } \\
\text { Two Secondary } \\
\text { Loops Filled and } \\
\text { Operated at } 520 \mathrm{~F}\end{array}$} & 1 & 358 & 59 & 500 & 89 & & & & & \\
\hline & & 2 & 384 & 72 & 570 & 110 & 330 & 56 & $<0.2$ & 0 & 386 \\
\hline & & 3 & - & - & - & - & & & & & \\
\hline \multirow[t]{3}{*}{ C } & \multirow{3}{*}{$\begin{array}{l}\text { Three Primary } \\
\text { Loops Operated, } \\
\text { Two Secondary } \\
\text { Loops Filled and } \\
\text { Operated At } 657 \text { F }\end{array}$} & 1 & 486 & 139 & - & - & & & & & \\
\hline & & 2 & 486 & 133 & 433 & 45 & 495 & 60 & +0.2 & -22 & 533 \\
\hline & & 3 & 486 & 133 & 433 & 45 & & & & & \\
\hline $\mathrm{C}_{1}$ & & & & & & & 504 & 60 & +0.4 & -44 & 520 \\
\hline $\mathrm{C}_{2}$ & & & & & & & 477 & 60 & +0.2 & -22 & 515 \\
\hline
\end{tabular}


Test $B$ was performed at $520 \mathrm{~F}$, and Tests $\mathrm{C}, \mathrm{C}_{1}$, and $\mathrm{C}_{2}$ at $657 \mathrm{~F}$. Results $\mathrm{C}_{1}$ and $\mathrm{C}_{2}$ were auxiliary measurements made during $\mathrm{Test} C$. The results are given in Table 4 .

To derive a three-loop temperature-dependent loss curve, the test results were analyzed in the following way. System losses were assumed to be directly proportional to the difference in system temperature and ambient temperature. Therefore, from Tests B and C, the $10 \mathrm{ss}$ of $386 \mathrm{kw}$ at $520 \mathrm{~F}$ and $523^{* k} \mathrm{kw}$ at $657 \mathrm{~F}$ imply an effective ambient temperature of $140 \mathrm{~F}$. If it is assumed that this interpretation is appropriate to all three-loop operations, the losses can then be described by Eq. (9) in which the absolute value for loss is taken from $T$ est $A$ results and $P_{H L}(T)$ is a function of average system temperature, $\mathrm{T}$.

$$
P_{H L}(T)=490 \mathrm{kw} \quad \frac{T-140}{530-140}
$$

Results including the derived three-loop curve are shown in Fig. 6.

Because the dissipative losses from the system represent such a small fraction of the at-power levels (less than one per cent at $100 \mathrm{Mw}$ ) no detailed assessment of error was required. However, from an examination of the reasonableness of the data, estimates of maximum error were obtained. Pump power was measured to within +7 per cent. The assumption that half the heater power was transferred to the sodium could introduce no more than a $30-\mathrm{kw}$ error. Linearity with ambient difference should introduce no more than a 40-kw error at $100 \mathrm{Mw}$. For the at-power tests, system temperature from which dissipative losses were determined was obtained by averaging system inlet and outlet temperatures. This approximation could have caused an error of up to $\pm 30 \mathrm{kw}$. Based on the se evaluations, a probable error for dis sipative losses of $\pm 70 \mathrm{kw}$ was obtained.

\section{HEAT BALANCE TEST}

Resultant average values for pertinent parameters observed during the three heat balance tests are listed in Table 5. Some necessary test parameters were not observed because of time limitations. However, it was known that the cold trap, pipe heaters and below-floor cooling were operating normally on the test days. Corrections for these and for pump input to the sodium based on measured speeds were made on the basis of previous test experience. Quantities derived from the basic data by use of the equations described in Section III-B-3 a re summarized in Table 6. The final calculated powers listed include all corrections. A detailed error analysis was performed in which all known sources of error were evaluated. Quantitative estimates of probable error and comments are summarized in Table 7.

* Average of losses for Tests $C, C_{1}$, and $C_{2}$ 


\section{TABLE 5 - TEST DATA - HEAT BALANCE *$$
\text { (Average Values) }
$$

\begin{tabular}{|c|c|c|c|c|c|c|c|}
\hline \multirow[b]{2}{*}{$\begin{array}{l}\text { Test } \\
\text { No. }\end{array}$} & \multirow[b]{2}{*}{$\begin{array}{l}\text { Loop } \\
\text { No. }\end{array}$} & \multicolumn{2}{|c|}{ Pump Speed, rpm } & \multirow[b]{2}{*}{$\begin{array}{c}\text { Water } \\
\text { Temp } \\
\mathrm{F} \\
\end{array}$} & \multicolumn{2}{|c|}{ Manometer Readings } & \multirow[b]{2}{*}{$\begin{array}{c}\text { Steam } \\
\text { Temp } \\
F \\
\end{array}$} \\
\hline & & Primary & Secondary & & $\begin{array}{c}\text { Ave rage } \\
\text { Height, } \\
\text { in. } \\
\end{array}$ & $\begin{array}{c}\text { Range of } \\
\text { Variation, } \\
\text { in. }\end{array}$ & \\
\hline \multirow[t]{3}{*}{1} & 1 & 627 & 390 & & 5.42 & 0.12 & 598.8 \\
\hline & 2 & 620 & 390 & 340.6 & 5.85 & 0.20 & 569.5 \\
\hline & 3 & 620 & 394 & & 5.05 & 0.10 & 603.3 \\
\hline \multirow[t]{3}{*}{2} & 1 & 510 & 380 & & 3.92 & 0.10 & 606.5 \\
\hline & 2 & 520 & 380 & 340.3 & 4.27 & 0.15 & 603.0 \\
\hline & 3 & 530 & 380 & & 4.23 & 0.08 & 627.8 \\
\hline \multirow[t]{3}{*}{3} & 1 & 510 & 380 & & 5.05 & 0.10 & 613.6 \\
\hline & 2 & 520 & 380 & 340.6 & 5.30 & 0.15 & 613.3 \\
\hline & 3 & 530 & 380 & & 5.29 & 0.15 & 636.8 \\
\hline
\end{tabular}

* For each test, steam pressure was 925 psia and system average temperature was $580 \mathrm{~F}$. 


\section{TABLE 6 - TEST RESULTS - HEAT BALANCE}

\begin{tabular}{|c|c|c|c|c|c|c|c|c|c|c|}
\hline \multirow[b]{2}{*}{$\begin{array}{l}\text { Test } \\
\text { No. }\end{array}$} & \multirow[b]{2}{*}{$\begin{array}{c}\text { Loop } \\
\text { No. }\end{array}$} & \multirow[b]{2}{*}{$\begin{array}{c}\text { Steam } \\
\text { Enthalpv, } \\
\text { Btu/1b } \\
\end{array}$} & \multirow[b]{2}{*}{$\begin{array}{c}\text { Water } \\
\text { Enthalpy, } \\
\text { Btu/1b } \\
\end{array}$} & \multirow[b]{2}{*}{$\begin{array}{c}\text { Water } \\
\text { Flow Rate, } \\
\text { lb/hr } \times 10^{-5} \\
\end{array}$} & \multirow[b]{2}{*}{$\begin{array}{c}\text { Loop } \\
\text { Output } \\
\text { Power, } \\
\text { Mw } \\
\end{array}$} & \multicolumn{4}{|c|}{ Corrections (Mw) for Power From: } & \multirow[b]{2}{*}{$\begin{array}{c}\text { Net } \\
\text { Corrected } \\
\text { Reactor } \\
\text { Power }(\mathrm{Mw}) \\
\end{array}$} \\
\hline & & & & & & Pumps & $\begin{array}{c}\text { Dissipative } \\
\text { Losses } \\
\end{array}$ & $\begin{array}{c}\text { Pipe } \\
\text { Heaters } \\
\end{array}$ & $\begin{array}{l}\text { Cold } \\
\text { Trap }\end{array}$ & \\
\hline \multirow{3}{*}{1} & 1 & 1256 & & 1.186 & 32.79 & & & & & \\
\hline & 2 & 1230 & 313 & 1.232 & 33.13 & -0.98 & +0.55 & -0.10 & +0.20 & 97 \\
\hline & 3 & 1260 & & 1.145 & 31.79 & & & & & \\
\hline \multirow{3}{*}{2} & 1 & 1263 & & 1.009 & 28.10 & & & & & \\
\hline & 2 & 1260 & 313 & 1.053 & 29.23 & -0.60 & +0.55 & -0.10 & +0.20 & 87 \\
\hline & 3 & 1280 & & 1.048 & 29.70 & & & & & \\
\hline \multirow{3}{*}{3} & 1 & 1269 & & 1.145 & 32.07 & & & & & \\
\hline & 2 & 1268 & 313 & 1.173 & 32.85 & -0.60 & +0.55 & -0.10 & +0.20 & 98 \\
\hline & 3 & 1286 & & 1.173 & 33.47 & & & & & \\
\hline
\end{tabular}




\section{Variables}

Feedwater Flow Rate, Steam Generator (Q) *: Coefficient of Discharge, Cq* Coefficient of Discharge, $\mathrm{Cq}^{*}$

Height of Manometer Fluid, h Density of Manometer Fluid, $\rho \mathrm{m}^{*}$ Density of Manometer Fluid, $\rho \mathrm{w}^{*}$ Probable Error in $\mathbf{Q}$

Water Side Enthalpy Change $(\Delta \mathrm{H})$ :

\section{Steam Temp \\ Water Temp}

Feedwater System Pressure

Probable Error in $\Delta \mathrm{H}$

\section{Power Corrections:}

\section{Dissipative Losses}

From Pumps

From Heaters

Cold Trap and Overflow System Losses

Probable Error in Power Correction

Non Stable Operation: $\underline{\text { Probable Error }}$

\begin{tabular}{lr}
1 & $\%$ \\
$0.5 \%$ \\
$1.2 \%$ \\
2 & $\%$ \\
2 & $\%$ \\
\hline 2 & $\%$
\end{tabular}

Ambiguity In Calibration Report, Original Calculation Subsequent Change In Calibration

From Oscillations And Reading Error

Probable Contaminants, Including Water

Probable Contaminants
$0.3 \%$
$0.3 \%$
Instrument, $\pm 4 \mathrm{~F}= \pm 3 \mathrm{Btu} / \mathrm{lb}$
Instrument, $\mp 2 \mathrm{~F}=\mp 2 \mathrm{Btu} / \mathrm{lb}$
Instrument, $\mp 12 \mathrm{psia}= \pm 1.5 \mathrm{Btu} / \mathrm{lb}$

$\frac{0.2 \%}{0.5 \%}$

$70 \mathrm{kw}$

$100 \mathrm{kw}$

$30 \mathrm{kw}$

$100 \mathrm{kw}$

$\overline{160 \mathrm{kw}}$

Estimated Experimental Error

Pump Power Error (+ $7 \%$ ) and Additional

Error From Heat Balance Test Procedures

Estimate of Trap Operations Due to Lack of Data

From All Sources

$2 \%$, Test 1

$4 \%$, Test 2

$3 \%$, Test 3
Based on Observed Temperature Drifts 
System (primary and secondary) sodium temperatures were examined for drift over the data-taking periods, to determine whether the feedwater flow rates were properly adjusted for the existing reactor power level. Two types of examinations were performed: (1) the system average temperature change, $\Delta \mathrm{T}_{\mathrm{S}}$, as implied by the change in readings of all available detectors, was obtained; and (2) the implied change in the temperature difference, $\Delta T_{p}$, between the hot and cold leg of each loop, was obtained for each pair of appropriate detectors. The range and average temperature changes as well as the implied drift rate are listed in Table 8 . The temperature averages are deemed accurate for repeatability of measurement to within a probable error of $+0.5 \mathrm{~F}$.

An understanding of the cause of the drift must be available from the experimental data, to relate the temperature changes, $\Delta \mathrm{T}_{\mathrm{p}}$, to power correction. For example, the degree of stability in the sodium flow rate of each primary and secondary coolant loop must be known. Variations in reactor power and ambient conditions must be known. The circumstances pertaining to all the tests were:

- Reactor power was constant, with any change being less than 1 per cent.

- Changes in primary and secondary flows were not implied by the data accumulated. It was found that changes of up to 3 per cent in the flow rate in any one loop would not have been detected.

- Final adjustments in water flow rates were made in some cases sufficiently close to the data-taking period to have caused some temperature changes.

Specifically, the temperature data of Table 8 , examinations of the recorder feedwater system (via a plant recorder-monitor), and the observations of the experimenters showed the following for the three tests:

TEST NO. 1 - The least drift was exhibited for this test, and no temperature drifts could be discerned; however, the data-taking period was insufficient to guarantee fully invariant levels.

TEST NO. 2 - The temperature of the sodium systems was increasing and the power measured at the feedwater terminals was not as accurately related to reactor power as for the other tests.

TEST NO. 3 - While reasonably stable temperatures were achieved, the drift information was insufficient to provide any reliable indication of drift. 
TABLE 8 - TEMPERATURE DRIFT DATA - HEAT BALANCE

$\underline{\text { Implied Drift }}$

\begin{tabular}{|c|c|c|c|c|c|c|c|}
\hline \multirow[b]{2}{*}{$\begin{array}{c}\text { Test } \\
\text { No. }\end{array}$} & \multirow[b]{2}{*}{$\begin{array}{c}\text { Length of } \\
\text { Data-Taking } \\
\text { Period, min } \\
\end{array}$} & \multicolumn{3}{|c|}{ In System Base Temperature* } & \multicolumn{3}{|c|}{ In Reactor $\mathrm{Na}$ Temperature Rise $\dagger$} \\
\hline & & Range, $F$ & Average, $F$ & $\begin{array}{c}\text { Rate of } \\
\text { Change, } F / h r \\
\end{array}$ & Range, $F$ & Average, $F$ & $\begin{array}{c}\text { Rate of } \\
\text { Change, } F / h \mathbf{r} \\
\end{array}$ \\
\hline 1 & 15 & -0.8 to 1.0 & 0.16 & 0.6 & -0.9 to -0.3 & -0.7 & -3 \\
\hline 2 & 5,6 & 0 to 1.3 & 0.6 & 7 & 0.5 to 1.0 & 0.7 & 8 \\
\hline 3 & 5,7 & -1.6 to 0.5 & -0.7 & -7 & -1.5 to 1.5 & -0.4 & -4 \\
\hline
\end{tabular}

* Average of 21 detectors

$\dagger$ Average of 8 pairs of detectors 
Therefore, since in general the drifts were not well monitored and there was insufficient reactor information, e.g., flow rate variations, the cause of the implied drifts could not be determined and corrections could not be made*. An estimate of probable difference between the actual and correct power removed by the feedwater system was made from the data of Table 8. The estimates, which are the judgement of the experimenters, are tabulated in Table 7.

Final test results are listed below. The error (in $\mathrm{Mw}$ ) included is an overall probable error which includes the effect of flow rate, enthalphy, and extraneous power source corrections as well as the estimated error due to drift.

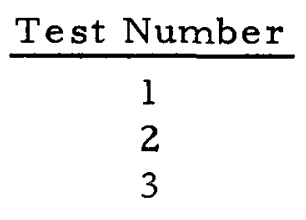

Final Value For

\begin{tabular}{|c|}
\hline Reactor Power (Mw) \\
\hline $97+3$ \\
\hline $87 \pm 4$ \\
\hline $98 \pm 4$ \\
\hline
\end{tabular}

A comparison of these results with the results of the nuclear power calibration extrapolated from low levels $(<1 \mathrm{Mw})$ is reviewed in Appendix $A$.

* Actually, $\Delta \mathrm{T}_{S}$ can be converted to power correction via the system heat capacity (see Section III). However, the corrections are $\leq 0.8 \mathrm{Mw}$ and, since they are smaller than the estimates of error due to drift, they have been ignored. 
$\bullet$

• 


\section{CONCLUSIONS}

Three tests designed to determine the thermal power of the Enrico Fermi reactor were successfully completed. Optimum accuracy was not obtained because compromises in reactor operating conditions were required, to allow for the performance of other tests.

- A probable error of \pm 4 per cent was found for the heat balance tests under the compromised conditions. Nevertheless, it is equal to the minimum achievable error of the nuclear power calibration technique.

- Under optimum conditions, the heat balance test error may be reduced to \pm 2 per cent, depending on the degree to which reactor drifts can be eliminated.

- The nuclear calibration agrees with the thermal calibration to within an average of 2 per cent. Considering that the error in the nuclear calibration itself was \pm 9 per cent, this agreement is quite satisfactory.

- Dissipative heat losses were determined with an error small enough to have essentially no effect on the heat balance error.

- By means of the thermal tests, the error in the calibration of the electromagnetic sodium flowmeters was reduced to \pm 6 per cent. 
$\bullet$ 


\section{APPENDIX A: COMPARISON OF HEAT BALANCE AND NUCLEAR POWER CALIBRATIONS}

Since a power calibration was also performed by nuclear techniques, comparison with the heat balance results represents an interesting trial of both experiments. An absolute fission counter is required for performing the nuclear experiment in the reactor core. The power level required for the calibration was restricted to a very low value of about 100 watts. Linear extrapolation to thermal test powers requires that detector response at increased powers be known. The problem and associated tests are described elsewhere. ${ }^{2}$ The nuclear calibration is summarized below.

The absolute fission counter was installed to measure fission rate at a location on the reactor midplane and several in. from the core center during low-power operations. Analytical calculations supported by in-reactor U-235 and U-238 fission distribution measurements were used to correlate this fission rate to total reactor fission rate, hence reactor power.* During the fission-counter $r$ un, a nuclear-level detector connected to the micromicroammeter was also monitored. A calibration of its response to reactor power was made based on the analytical calculation. Near the end of the lowpower tests, the nuclear chamber was changed to the one designated ND-1, with sufficient data taken to provide calibration of the new chamber. The ND-1 detector provided nuclear monitorings during the heat balance tests which, however, followed a disturbance in detector location that compromised the nuclear calibration. High temperatures induced in the graphite during other tests threatened to damage detector electrical leads and all chambers were removed from their locations by withdrawing the $30-\mathrm{ft}-\mathrm{long}$ counter-tube assemblies from their operational locations. Each held from two to four detectors rigidly affixed in its internal structure. After temperatures had been lowered, the counter-tube assemblies were carefully replaced at their former elevations and azimuths. Later measurements indicated that the replacement was not as reproducible as expected and that a shift in detector sensitivity of unknown amounts of 8 per cent or more could have occurred. The probable error of the resultant nuclear calibration for high-power levels was estimated to be +9 per cent. ${ }^{2}$ Optimum error achievable would be no smaller than \pm 4 per cent by this nuclear technique.

The measured sensitivity was nevertheless employed in converting ND-1 readings to power indications during the heat balance tests. Other

* For conversion to power, a value of $194 \mathrm{Mev} /$ fission and appropriate values for capture events were used; this implies that all $\beta$-and $\gamma$-decay energy was released in the reactor. This assumption produces an overestimate of power of about 3 per cent for an operating period of one hour. 
detectors, which indicated relative level, were also monitored. Comparative results (Table A. 1 and Fig. A. 1) indicate that the nuclear and thermal power calibrations produce results in agreement within an average of 2 per cent. Considering the probable errors in thermal calibration (4 to $5 \%$ ), nuclear calibration (4\%), and detector reinstallation $(7 \%)$, the agreement between the two methods is entirely satisfactory. It is fortuitous that the agreement is so close.

TABLE A.1 - COMPARISON OF THERMAL AND NUCLEAR DETERMINATIONS OF REACTOR POWER

Response of Nuclear

Detectors To That of

ND-1, arbitrary units

Reactor Power, Mw

Test

From Nuclear

No.

$\mathrm{PR} 1 / \mathrm{ND} 1$

$\underline{\mathrm{PR} 2 / \mathrm{ND} 1 \mathrm{PR} 3 / \mathrm{ND} 1}$

Test

Calibration of ND-1*

1

0.583

0.600

0.578

97

98.6

2

0.583

0.603

0.581

87

90.2

$3 \quad 0.583$

0.602

0.579

98

99.5

* ND-1 Reading (amps) $\times 2.71 \times 10^{12}$ watts/amp 


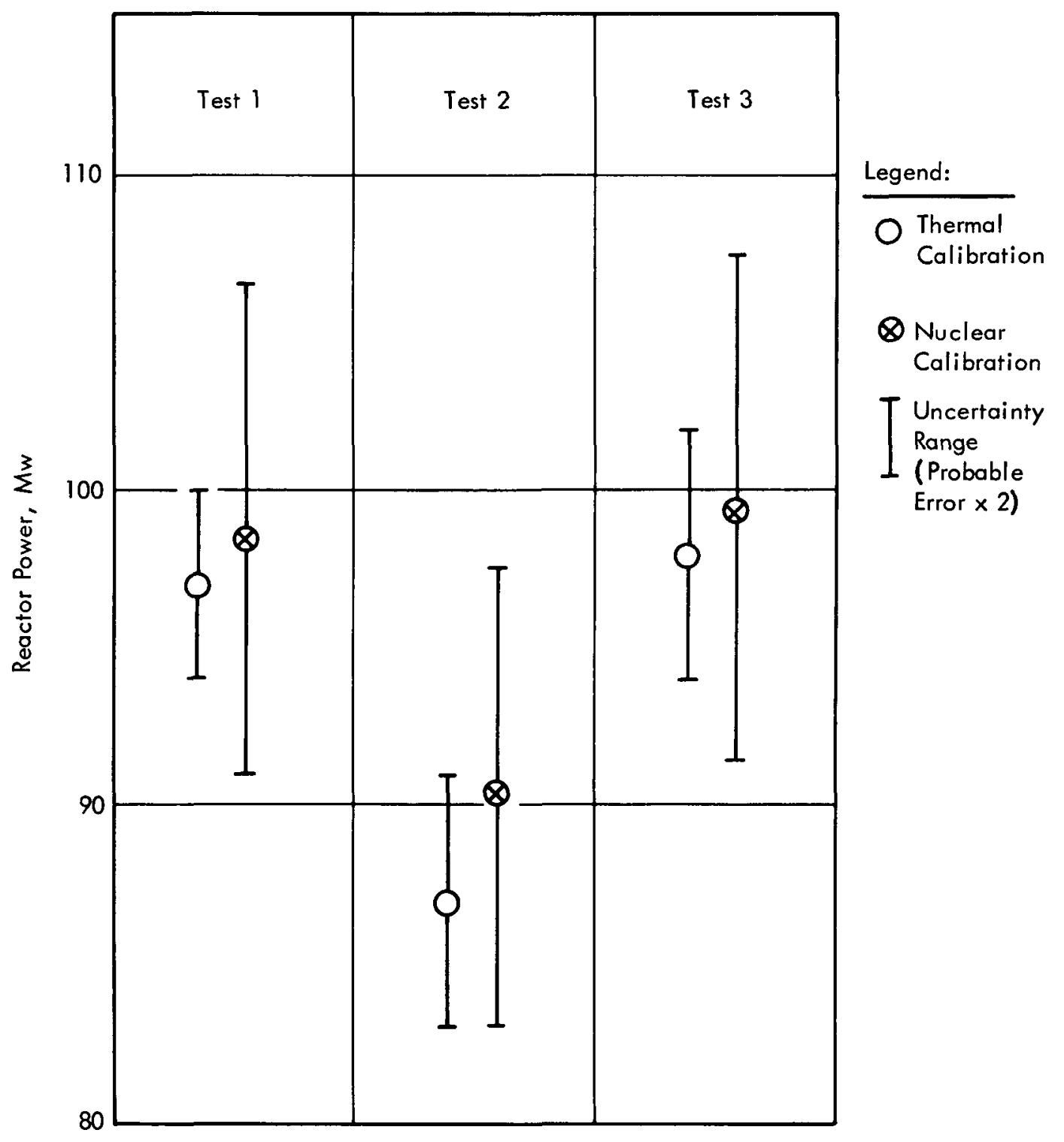

FIG. A-1 COMPARISON OF THE NUCLEAR POWER CALIBRATION WITH THE THREE THERMAL POWER CALIBRATIONS 


\section{APPENDIX B: SODIUM FLOWMETER CALIBRATIONS}

Heat balance measurements in the primary and secondary sodium loops were not used in the power calibration because of inaccurate sodium flowmeter calibrations. Having once performed the thermal power measurement, the results could be used, in turn, to obtain flowmeter calibrations of much higher accuracy. Thus, the power being transferred from the primary to the secondary system in the IHX of loop $x$, is:

$$
\mathrm{P}_{\mathrm{x}}=\Delta \mathrm{T}_{\mathrm{x}, \mathrm{p}} \cdot \mathrm{F}_{\mathrm{x}, \mathrm{p}} \overline{\mathrm{C}}=\Delta \mathrm{T}_{\mathrm{x}, \mathrm{s}} \cdot \mathrm{F}_{\mathrm{x}, \mathrm{s}} \overline{\mathrm{C}}
$$

to within an error much less than that in the heat balance test.

$$
\begin{aligned}
\Delta \mathrm{T}= & \text { temperature change of sodium when passing through the } \\
& \text { indicated side of the IHX, } \mathrm{F} \\
\mathrm{F}= & \text { sodium flow rate in indicated } 100 \mathrm{p}, \mathrm{lb} / \mathrm{hr} \\
\overline{\mathrm{C}}= & \text { mean specific heat of sodium, } \mathrm{Mw} / \mathrm{lb} / \mathrm{F} \\
\mathrm{p}= & \text { primary side of IHX } \\
\mathrm{s}= & \text { secondary side of } \mathrm{IHX} \\
\mathrm{x}= & \text { loop number }(1,2 \text {, or } 3)
\end{aligned}
$$

The mean specific heat of sodium was derived for an average system temperature, $T$, from the following equation: 4

$$
\overline{\mathrm{C}}^{\prime}(\mathrm{Btu} / \mathrm{lb} / \mathrm{F})=0.3445-0.750 \times 10^{-4} \mathrm{~T}+0.3125 \times 10^{-7} \mathrm{~T}^{2}
$$

Values of power were obtained from Table 6, to which corrections were applied for extraneous sources assumed to be one third of thos e tabulated. Temperatures were those read (including corrections) on the detectors TE-201 and TE -209 in the primary loops and the experimental test thermocouples in the secondary loops. Results are listed in Table B. 1 .

The accuracy of the flowmeter calibration depends on the accuracy of measurement of temperature difference. Accuracy in the primary system is most strongly dependent on the TE-201 transmission signal circuits. The detectors were pipe-wall mounted in the secondary system. Because of these conditions, an accuracy of about 3 per cent was estimated for temperature difference; this gave an overall average of 6 per cent for the probable error in flowmeter calibration.

* This method yields acceptably accurate corrections, since their magnitudes are very small compared to reactor power. 


\section{TABLE B.1 - FERMI SODIUM FLOWMETER CALIBRATION}

Primary System Secondary System Temperature, $\mathbf{F}$ Temperature

Loop Flow Rate $\times 10^{6} \mathrm{~b} / \mathrm{hr}$

Test Date

Loop Number Hot Leg Cold Leg Hot Leg Cold Leg

$\$$
July 11, 1966

(From Test No.1)

1656

2

3

656

673

12,1966

(From Test No. 3)
2

673

3
555

554

552

\begin{abstract}
543
\end{abstract}
547

553
631

625

625

630

631

637$$
\Delta \mathrm{T}, \mathbf{F}
$$

$$
\text { Loop }
$$
Primary Secondary

32.7

3. 0

102

10

31.7

104

110
130

126

32.7

33.3

120
3.32

3.34

3.16

3.15

.12

$2.85 \quad 3.15$

$3.04 \quad 3.02$ 
An example of the use of the flowmeter calibration is offered in the following brief discussion. Flowmeter indicators at Fermi contain a nonlinear correction factor programmed into the readout circuitry. The correction was obtained from tests of pump characteristics. Comparison of of the "as-read" values for flow with the measured values of Table B. 1 showed that the'as-read"primary loop values were 10 per cent too high (average) and the secondary readings were correct within 2 to 3 per cent. * Further, the "read-to-measured" ratio of July 11 for the primary loops, when meas ured flow was $3.48 \times 10^{6} \mathrm{lb} / \mathrm{hr} /$ loop average, was 4 per cent lower than July 12 for which flow had been reduced to $2.86 \times 106 \mathrm{lb} / \mathrm{hr} / 100 \mathrm{p}$. The dif ference implied an error in the assignment of the nonlinear conversion in the flowmeter correction factor; consequentlys a re-examination was instituted. 5 This resulted in a new conversion much more in agreement with the heat balance flow calibrations.

* Following a somewhat arbitrary 20 per cent adjustment in the indicator readings. 


\section{REFERENCES}

1. "Technical Information and Hazards Summary Report, Enrico Fermi Atomic Power Plant," Vols 1-9, revised March, 1964, Atomic Power Development Associates, Inc., 1964.

2. Callen, R. C. and Page, E. M., "Nuclear Power Calibration and Linearity Investigation of Neutron Detectors, Enrico Fermi Reactor," APDA-NTS-19, (to be published, 1968).

3. Keenan, J. H. and Keyes, F. G., Thermodynamic Properties of Steam, John Wiley and Sons, Inc., New York, 1936.

4. Burdi, G. F., Snap Technology Handbook, Vol. 1, Liquid Metals, NAA-SR -8617, August, 1964.

5. Meshii, Toshio, "New Calibration Curves of 14" Primary Sodium Flowmeters," APDA Internal Memorandum S-67-327, September 20, 1967. 